\section{УДК 616.62-006.6:577.2]-07}

\section{Молекулярні підтипи м'язово-інвазивного раку сечового міхура}

\author{
Оксана Сулаєва ${ }^{1}$, Олексій Селезньов ${ }^{1}$, Дмитро Шапочка ${ }^{1}$, \\ Роман Пономарчук ${ }^{1}$, Олександр Стаховський ${ }^{2}$, \\ Наталія Стефінів ${ }^{3}$ \\ ${ }^{1}$ Медична лабораторія CSD, м. Київ, Україна \\ ${ }^{2}$ Національний інститут раку, м. Київ, Україна \\ ${ }^{3}$ Київський національний університет ім. Т. Шевченка, \\ Інститут біології та медицини, м. Київ, Україна
}

Проаналізовано сучасний стан питання про молекулярні підтипи м'язово-інвазивного раку сечового міхура (MIРСМ), їхні ключові біомаркери та рекомендовані підходи до лікування. Відомо кілька варіантів молекулярних класифікацій РСМ, враховуючи версії медичного коледжу Бейлора (BCM), Університету Північної Кароліни (UNC), Центру раку МД Андерсона (MDA), проєкту Атлас генома раку (TCGA) і класифікацію Лунда (Швеція). Сьогодні розроблена консенсусна міжнародна класифікація молекулярних підтипів MI-PCM, яка не тільки поглибила розуміння біології РСМ, а й виявила взаємозв'язок певних геномних порушень з конкретними морфологічними підтипами та клінічним перебігом РСМ. Молекулярні класифікації МI-PCM допомагають не тільки прогнозувати перебіг пухлинного процесу, а й стратифікувати пацієнтів за ймовірною відповіддю на хіміотерапію та імунотерапію. Однак впровадження молекулярної класифікації РСМ в клінічну практику має певні обмеження та потребує проведення валідаційних досліджень.

\section{OPEn OACCess}

DOI: $10.25040 /$ ntsh2020.01.09

Для листування:

м. Київ, вул. Васильківська, 45, Україна, 03022

E-пошта: o.sulaieva@csd.com.ua

Стаття надійшла: 27.02.2020

Прийнята до друку: 17.03 .2020

Опублікована онлайн: 15.04 .2020

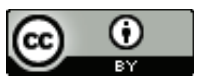

(с) Оксана Сулаєва, Олексій Селезньов, Дмитро Шапочка, Роман Пономарчук, Олександр Стаховський, Наталія Стефінів, 2020

ORCID IDs

Oksana Sulaieva

http://orcid.org/0000-0002-9614-4652

Oleksii Seleznov

https://orcid.org/0000-0002-9950-9418

Dmytro Shapochka

https://orcid.org/0000-0001-5744-7872

Roman Ponomarchuk

https://orcid.org/0000-0002-8620-6362

Oleksandr Stakhovsky

https://orcid.org/0000-0002-7528-551X

Natalia Stefiniv

https://orcid.org/0000-0001-8872-0472

Конфлікт інтересів: Автори декларують, що немає конфлікту інтересів.

Особистий внесок авторів:

Всі автори в рівній мірі брали участь у підготовці цього огляду. Всі автори прочитали та затвердили остаточний варіант рукопису.

Фінансування. Підготовка цього огляду не потребувала фінансування.

Ключові слова: рак сечового міхура, молекулярна класифікація, персоналізована терапія. 


\section{OPEN ОACCESS}

DOI: $10.25040 /$ ntsh2020.01.09

For correspondence:

45, Vasylkivska street, Kyiv, Ukraine, 03022

E-пошта: o.sulaieva@csd.com.ua

Received: Feb 27, 2020

Accepted: March 17, 2020

Published online: Apr, 15, 2020

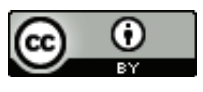

(C) Oksana Sulaieva, Oleksii Seleznov,

Shapochka D.,

Roman Ponomarchuk,

Oleksandr Stakhovski,

Natalia Stefiniv, 2020

ORCID IDs

Oksana Sulaieva

http://orcid.org/0000-0002-9614-4652

Oleksii Seleznov

https://orcid.org/0000-0002-9950-9418

Dmytro Shapochka

https://orcid.org/0000-0001-5744-7872

Roman Ponomarchuk

https://orcid.org/0000-0002-8620-6362

Oleksandr Stakhovsky

https://orcid.org/0000-0002-7528-551X

Natalia Stefiniv

https://orcid.org/0000-0001-8872-0472

Disclosures. Authors state that there is no conflict of interest

Author Contributions:

All authors were equally involved in the preparation of this review. All authors have read and approved the final version of the manuscript.

Funding. This review did not require funding.

\section{UDC 616.62-006.6:577.2]-07}

\section{Molecular subtypes of muscular invasive bladder cancer}

Oksana Sulaieva ${ }^{1}$, Oleksii Seleznov ${ }^{1}$, Dmytro Shapochka, Roman Ponomarchuk ${ }^{1}$, Oleksandr Stakhovski ${ }^{2}$, Natalia Stefiniv

${ }^{1}$ Medical Laboratory CSD, Kyiv, Ukraine ${ }^{2}$ National Institute of Cancer, Kyiv, Ukraine ${ }^{3}$ Taras Shevchenko National University of Kyiv, Institute of Biology and Medicine, Kyiv, Ukraine

This review analyzes the current view on molecular subtypes of muscle-invasive bladder cancer (MI-BC), its key biomarkers, and recommended treatment approaches. Several variants of molecular classifications of $B C$ are known, including the classification of Baylor College of Medicine (BCM), the University of North Carolina (UNC), the MD Anderson Cancer Center (MDA), the Atlas Cancer Genome Project (TCGA), and Lund (Sweden). Nowadays, a consensus international classification of MI-BC has been developed, which not only deepened understanding of the biology of the BC but also showed the relationship of certain genomic disorders with specific morphological subtypes, as well as the clinical pass of the BC. The developed variants of molecular classifications of MI-BC allow not only to predict the course of the tumour process but also stratify patients according to the likely response to chemotherapy and immunotherapy. However, the implementation of molecular classification of MI-BC into clinical practice has several limitations and requires validation studies.

Keywords: Bladder cancer, molecular classification, personalized therapy.

Cite this article as: Sulaieva O, Seleznov O, Shapochka D, Ponomarchuk R, Stakhovsky O, Stefiniv N. Molecular subtypes of muscular invasive bladder cancer. Proc Shevchenko Sci Soc Med Sci 2020;59(1):8592. https://doi.org/10.25040/ntsh2020.01.09

Молекулярна патологія і генетика стали невіддільною частиною сучасної клінічної медицини, особливо - онкології. Комплексне вивчення генетичних альтерацій, специфіки експресії генів у комбінації з клініко-лабораторними, інструментальними й патогістологічними даними дає змогу краще зрозуміти біологію різних варіантів карцином, а також $\epsilon$ основою розробки молекулярної класифікації пухлин [2, 4, 17] і розвитку персоналізованої медицини [3, 18, 20, 35].

Прикладом успішної молекулярної класифікації $\epsilon$ рак грудної залози, визначення молекулярних підтипів якого суттєво полегшує вибір оптимальної терапії $[9,30]$. 3 огляду на зростаючу частоту раку сечового міхура (РСМ) і смертності від цієї патології, а також економічні витрати на моніторинг і лікування пацієнтів з уротеліальними неоплазіями, очевидно, що розробка молекулярної класифікацій РСМ була й залишається однією з найбільш «гарячих» тем онкоурології $[5,22]$. У цьому випадку молекулярне типування уротеліальних пухлин спрямовано на вирішення важливих фундаментальних питань і клінічних задач, враховуючи: 
- визначення спектра генів, залучених у патогенез РСМ;

- верифікацію драйверних мутацій і епігенетичних механізмів, пов'язаних з інвазією РСМ в м'язову оболонку;

- визначення взаємозв'язку між генетичною експресією та патогістологічними характеристиками пухлин СМ;

- валідацію прогностичних біомаркерів і їхню кластеризацію;

- оптимізацію вибору потенційних мішеней терапії для різних молекулярних підтипів РСМ.

Вже були спроби розробити і впровадити молекулярну класифікацію РСМ [10, 11, 27, 34]. Складність цього завдання пов'язана з надзвичайною гетерогенністю РСМ у клініко-патогенетичному та молекулярному аспектах. При РСМ, крім численних хромосомних реаранжировок, ідентифіковані генетичні альтерації в понад 50 онкогенах і генах-супресорах пухлинного росту $[6,8]$. Варто зазначити, що аналіз транскриптому прискорив процес класифікації РСМ, а також визначення прогностичних і предиктивних чинників, які допомагають оптимізувати вибір терапії [7, 15].

Не менш серйозною проблемою в історії розробки молекулярної класифікації РСМ стали різні методологічні аспекти проведених раніше досліджень. Спроби класифікації РСМ були виконані на різних за розміром і складом вибірках пацієнтів, із застосуванням різних методів, генних класифікаторів і біомаркерів. Проте накопичені дані дають змогу все-таки говорити про можливість виділення різних молекулярних підтипів РСМ, які мають свій морфологічний і молекулярний портрет, характеризуються різним прогнозом і чутливістю до терапії. В рамках цього огляду провели аналіз сучасного стану питання про МI-PCM, їхні ключові біомаркери та рекомендовані підходи до лікування.

До найвідоміших і значущих класифікацій зачисляють класифікації медичного коледжу Бейлора (ВСМ), Університету Північної Кароліни (UNC), Центру раку МД Андерсона (MDA), проєкту Атлас генома раку (TCGA) і Лунда (Швеція) [12, 14, 19, 23, 28, 32]. Кожна з цих класифікацій налічує кілька версій і $€$ різною кількістю молекулярних підтипів. у 2012 р. група дослідників з Baylor College of Medicine's запропонувала класифікацію, яка базувалася на даних про програму стандартного диференціювання клітин уротелію [26]. Згідно з базовою концепцією, вихідним джерелом лінії клітин уротелію $€$ самовідновлювальні стовбурові клітини (СК), що експресують цитокератин 14 (KRT14) - KRT14 / Thy-1 / CD44. Вони дають початок усім іншим клітинам уротелію. Процес диференціювання клітин уротелію (і всюди дані по тексту) починається з експресії набору KRT5 / KRT17 / CD44. На наступному етапі клітини набувають експресію KRT8 / 18, а термінально диференційовані епітеліоцити поверхневого шару уротелію (клітини-парасольки) експресують уроплакіни й KRT20 [25]. Автори виявили, що експресія KRT14 за відсутності KRT5 і KRT20 в клітинах PCM асоційована з найнижчим рівнем диференціювання РСМ і гіршим прогнозом $[8,13]$. Враховуючи рівень диференціювання пухлинних клітин, запропонували виділити три підтипи РСМ: базальний, з проміжним рівнем диференціювання та диференційований РСМ. До того ж, автори виявили прогностичну значущість експресії маркерів ракових стовбурових клітин, включаючи KRT14, ALDH1A1 i p63 [33]. Пізніше з'ясували, що група KRT14 + пухлин (базальний підтип) була резистентна до неоад'ювантної терапії цисплатином [15]. Використовуючи 18-генний класифікатор, який охоплював маркери диференціювання, автори підтвердили, що базальноклітинні пухлини справді багаті стовбуровими та прогеніторними клітинами уротелію, які експресують такі маркери: KRT14 / 5/17, CD44 і CD49, а також сигнальні молекули EGFR, JAK2 i STAT3 [13, 33].

У класифікації Університету Північної Кароліни - UNC дослідницька група, за аналогією з раком грудної залози, запропонувала виділення базального та люмінального підтипів [1]. Кожен з цих підтипів характеризувався експресією відповідних сигнатур. Набір маркерів базального підтипу охоплював CD44, KRT5, KRT6, KRT14, CDH3. Люмінальний підтип характеризувався експресією CD24, FOXA1, GATA3, ERBB2, ERBB3, XBP1 i KRT20 [10, 28]. Крім того, автори виявили, що для базального підтипу РСМ характерне порушення в генах RB1 і NFE2L2, тоді як у люмінальній пухлинах переважали альтерації генів FGFR3 і KDM6A [32]. Пізніше в цій класифікації виділили ще один підтип - 3 низькою експресією клаудина $[1,25]$. 
Класифікація, розроблена групою дослідників MD Anderson Cancer Center (MDA), початково передбачала виділення 3 молекулярних підтипів: люмінальний, базальний і р53-подібний [28]. Пізніше було виділено ще два підтипи. У підсумку класифікація була розширена до 5 підтипів: Люмінальний, Люмінальний-Р53, Базальний, Базальний-Р53 і двічі-негативний [32]. Незалежно від цього було проведено дослідження в рамках проєкту Атлас генома раку (TCGA). Група TCGA провела повноекзомне секвенування пухлин 130 пацієнтів з РСМ, ідентифікувавши у цьому випадку 39,312 соматичних мутацій (враховуючи 38,012 точкових мутацій і 1,138 інсерцій / делецій), з'ясувавши, що в середньому в межах однієї карциноми трапляється 7.7 чи 5.5 на Mb точкових мутацій $[7,15,19]$. Крім вже відомих генетичних альтерацій, TCGA проєкт ідентифікував залучення багатьох інших генів, альтерації яких мали клінічну важливість при РСМ. До них зачисляють: MLL (27\%), CDKN1A (14\%), ERCC2 (12\%), STAG2 (11\%), RXR (9\%), ELF3 (8\%), NFE2L2 (8\%), KLF5 (8\%), TXNIP (7 \%), FOXQ1 (5\%), RHOB (5\%), FOXA1 (5\%), PAIP1 (5\%), BTG2 (5\%), ZFP36L1 (5\%), RHOA (4\%) i CCND3 (4\%). Внаслідок кластеризації даних mRNA, miRNA і даних протеомічного аналізу сигнальних шляхів у рамках проєкту TCGA версії 2014 року було ідентифіковано чотири молекулярні підгрупи МI-PCМ: пухлини кластерів I, II, III, і IV. Кластер I («папіляроподібний» тип) охоплював пухлини з папілярною морфологією, які характеризуються високою частотою мутацій або ампліфікації FGFR3 за низької експресії miR-99a i miR100, що обмежують FGFR3 сигналізацію [19, 33]. Пухлини з альтераціями FGFR3 можуть відповідати на інгібітори FGFR або мішені низхідного сигнального шляху. Уротеліальні карциноми https://www.nature.com/articles/ nature12965 - ref22класів I і II експресували маркери уротеліального диференціювання, враховуючи уроплакіни (наприклад, UPKЗА). Водночас ці пухлини експресували маркери GATA3 і FOXA1 (типові для люмінального типу А карцином молочної залози) [8]. Крім того, РСМ кластерів I й II часто мав високий рівень експресії HER2 (ERBB2) і підвищений рівень експресії естрогенових рецепторів бета (ESR2), що визначає їхню потенційну чутливість до гормональної те- рапії, враховуючи тамоксифен і ралоксифен, а також до інгібіторів HER2 [23]. Клас III («базально/плоскоклітиноподібний») мав характеристики, подібні з базальним типом раку молочної залози, плоскоклітинним раком голови та шиї, а також раком легенів $[6,19]$. Клас IV мав ознаки епітеліально-мезенхімальних трансформації (ЕМТ), експресував низький рівень Е-кадгерина і miR-200 [23]. При всіх перевагах, класифікація TCGA мала один важливий недолік просунутий аналіз геномних альтерацій і сигнатур пухлинних клітин не брав до уваги той важливий факт, що пухлина початково $€$ гетерогенною системою, яка охоплює не тільки пухлинні клітини, а й клітини мікрооточення. Ці недоліки усунули в пізнішій версії класифікації TCGA версії 2017 року (див. нижче).

Важливим кроком у розвитку концепції молекулярної класифікації РСМ стала класифікація групи дослідників університету Лунда, яка враховувала характеристики клітин пухлини та пухлинного мікрооточення [12, 34]. Молекулярні підтипи за версією Лунда враховують не тільки специфіку геномної експресії, а й гістологічні параметри та біологічні характеристики пухлин, включаючи маркери проліферації, гістогенетичного диференціювання, сигнатури клітин пухлинного мікрооточення (Т-лімфоцитів, мієлоїдних клітин, компонентів позаклітинного матриксу) $[2,20,26,34]$. В основі алгоритму цієї класифікації передбачено визначення гістогенетичного походження пухлинних клітин за такими напрямами диференціювання: уротеліальна, плоскоклітинна, мезенхімальна, нейроендокринна [12]. На підставі цього виділили такі молекулярні підтипи:

- уротеліальний (маркери: FGFR3 +, CCND1 +, RB1 +, p16-);

- геномно-нестабільний (маркери: FGFR3-, CCND1-, RB1-, p16 +);

- мезенхімальний / інфільтрований (маркери: Vim +, Zeb2 +, CDH1-, EpCAM-);

- плоскоклітинний (маркери: KRT5 +, KRT14 +, FOXA1-, GATA3-)

- нейроендокринний (маркери: TUBB2B +, EPCAM +, CDH1-, GATA3-).

Наступні роботи в цій сфері призвели до виділення додаткових підкласів пухлин у рамках уротеліального (люмінального) типу 


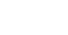

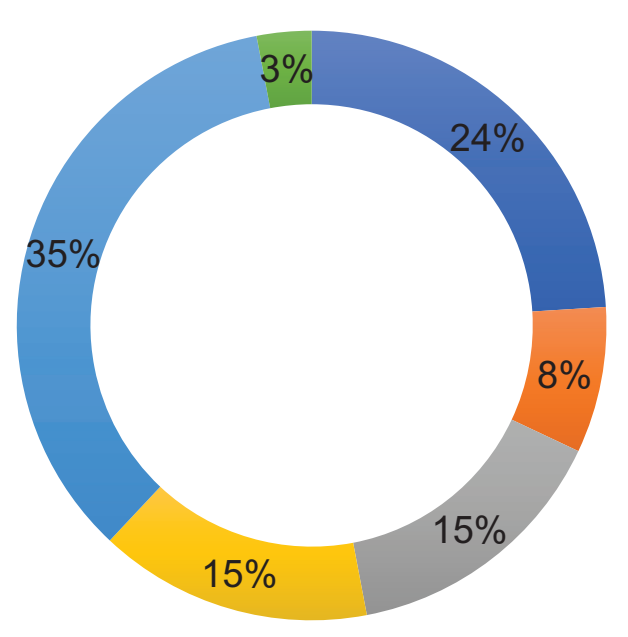

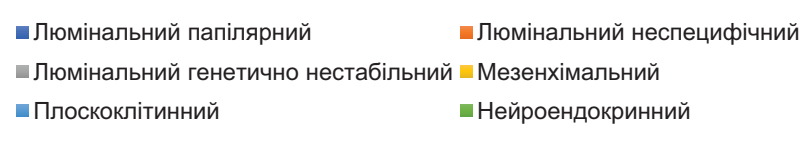

Рисунок 1. Молекулярні підтипи МI-PCM

$[14,34]$. Крім того, в останні роки проведені масштабні дослідження, спрямовані на інтеграцію, накопичених різними групами, даних. Одним з таких досліджень $€$ праця Tan TZ et al. (2019) виконана на основі аналізу даних 2411 пацієнтів з включенням МHIPCM і MI-PCM. Ця робота чітко формує уявлення про виживаність пацієнтів з різними молекулярними прототипами РСМ і клінічно значущі молекулярні мішені для персоналізованої терапії [31].

Проведені у 2014 р. дослідження щодо молекулярної класифікації МI-PCM, а також результати класифікації Лунда, стали основою перегляду TCGA-класифікації із залученням додаткової когорти пацієнтів. 3 огляду на це у 2017 р. у світ вийшла оновлена класифікація TCGA, яка передбачає виділення 5 молекулярних підтипів МI-РСМ, що відрізняються не тільки генетичними сигнатурами і маркерами, але також морфологією, прогнозом і чутливістю до різних варіантів терапії (див. табл. 1) [16]. Варто зазначити, що така класифікація набула значної популярності. Ініціювали низку досліджень 3 валідації цієї класифікації [21, 24, 29, 36].

Однак історія молекулярного типування MIPCМ на цьому не закінчилася. Спільна робота протягом кількох років 20 дослідницьких груп з 10 країн привела до розробки єдиної консенсусної класифікації МI-РСМ, пред- ставленої у 2019 р. Ця класифікація розроблена на підставі аналізу даних генома, транскриптому та протеому 1750 пухлин, 3 урахуванням патогістологічних і клінічних даних [31]. Згідно з консенсусною класифікацією, МI-PCM представлений 6 класами. 1. Люмінальний папілярний тип (24\%). 2. Люмінальний неспецифічний тип (8\%). 3. Люмінальний нестабільний тип (15\%). 4. Багатий стромою варіант (15\%).

5. Базальний / плоскоклітинний (35\%). 6. Нейроендокриноподібний (3\%).

Ці класи відрізняються за механізмами канцерогенезу, вираженості інфільтрації імунними та стромальними клітинами, а також гістологічними і клінічними характеристиками (див. рис. 1).

Така класифікація детальніша, відображає біологічні та клінічні аспекти РСМ. Вона охоплює широку гетерогенність молекулярно-генетичних порушень, які спостерігаються при РСМ. Це дає змогу розраховувати на ефективність її застосування при виборі індивідуалізованої стратегії лікування пацієнтів з РСМ. У цьому випадку класифікація дає чітке уявлення про взаємозв'язки між морфологічним фенотипом і молекулярним підтипами РСМ.

Проте, святкуючи успіх, не варто забувати про обмеження застосування молекулярної класифікації РСМ. По-перше, в основі молекулярної класифікації $€$ аналіз даних транскриптоміки на підставі оцінки експресії РНК, наприклад, при використанні заморожених тканин, тоді як в стандартній практиці працюють з фіксованим у формаліні та залитим в парафінові блоки матеріалом $[16,21]$. Друге важливе обмеження полягає в тому, що молекулярне субтипування РСМ до і після неоадювантної XТ може дати абсолютно різні результати [24]. I нарешті, відповідь МI-PCM на терапію може залежати від експресії додаткових генів, аналіз яких не передбачений класифікаторами [29].

Отож, сьогодні розроблена консенсусна міжнародна класифікація МI-PCM, яка не тільки поглибила розуміння біології РСМ, а й довела взаємозв'язок конкретних геномних з конкретними молекулярними підтипами та клінічним перебігом РСМ. Розроблені варіанти молекулярних класифікацій МHI-PCM і 
MI-PCM дають змогу не тільки прогнозувати перебіг пухлинного процесу, а й стратифікувати пацієнтів за ймовірною відповіддю на хіміотерапію та імунотерапію, проте цей аспект потребує проведення подальших валідаційних досліджень.

Таблиця 1

\section{Характеристика молекулярних підтипів МI-PCМ згідно консенсусної класифікації}

\begin{tabular}{|c|c|c|c|c|}
\hline $\begin{array}{l}\text { Молекулярні } \\
\text { підтипи }\end{array}$ & $\begin{array}{c}\text { Генетичні } \\
\text { вимірювання }\end{array}$ & Гістологія & IГX-маркери & $\begin{array}{c}\text { Клінічні } \\
\text { характеристики, } \\
\text { лікування }\end{array}$ \\
\hline $\begin{array}{c}\text { Люмінальний } \\
\text { папілярний }\end{array}$ & $\begin{array}{c}\text { Експресія: } \\
\uparrow \text { FGFR3 } \\
\downarrow \text { CDKN } \\
\uparrow F O X A 1 \\
\uparrow G A T A 3 \\
\text { Myтаціï: } \\
\text { FGFR3 }(40 \%) \\
\text { KDM6A (38\%) } \\
\text { STAG2 (22\%) } \\
\end{array}$ & Папілярна морфологія & $\begin{array}{c}\text { E-кадгерин+ } \\
\text { UPK-1-3+ } \\
\text { KRT20+ } \\
\text { P-кадгерин+ } \\
\text { KRT5+ }\end{array}$ & $\begin{array}{c}\text { HMI-PCM } \\
\text { PCM стадія } 2 \\
\text { 3В - } 4 \text { роки } \\
\\
\text { Мішені терапії: } \\
\text { FGFR3 } \\
\text { ERBB2 } \\
\text { EGFR+ }\end{array}$ \\
\hline $\begin{array}{l}\text { Люмінальний } \\
\text { неспецифічний }\end{array}$ & $\begin{array}{c}\text { Експресія: } \\
\uparrow \text { PPAR } \chi \\
\uparrow \text { RXRA } \\
\uparrow \text { GATA3 } \\
\uparrow \text { FOXA1 } \\
\uparrow \text { FOXM } \\
\text { Myтаціï: } \\
\text { ELF3 }(35 \%)\end{array}$ & $\begin{array}{c}\text { Мікропапілярний } \\
\text { варіант }\end{array}$ & $\begin{array}{l}\text { E-кадгерин+ } \\
\text { UPK-1-3+ } \\
\text { KRT20+ } \\
\text { P-кадгерин- } \\
\text { KRT5- }\end{array}$ & $\begin{array}{c}\text { Пацієнти старшого } \\
\text { віку } \\
\text { 80+ років } \\
\text { 3B - 1,8 рік } \\
\text { Мішені терапії: } \\
\text { ERBB2 } \\
\text { EGFR+ } \\
\text { FGFR3 }\end{array}$ \\
\hline $\begin{array}{l}\text { Люмінальний } \\
\text { нестабільний }\end{array}$ & $\begin{array}{c}\text { Експресія: } \\
\uparrow \text { PPAR } \chi \\
\uparrow \text { E2F3 } \\
\uparrow \text { ERBB2 } \\
\text { APOBEC+ } \\
\text { Мутації: } \\
\text { TP53 }(76 \%) \\
\text { ERCC2 }(22 \%) \\
\text { TMB+ }\end{array}$ & $\begin{array}{l}\text { Варіабельна } \\
\text { морфологія }\end{array}$ & $\begin{array}{l}\text { E-кадгерин+ } \\
\text { UPK-1-3+ } \\
\text { KRT20+ } \\
\text { P-кадгерин- } \\
\text { KRT5- }\end{array}$ & $\begin{array}{c}\text { 3В - 2,9 роки } \\
\text { Мішені терапії: } \\
\text { Імунні чекпоїнти }\end{array}$ \\
\hline $\begin{array}{l}\text { Мезенхімаль- } \\
\text { ний (багатий } \\
\text { стромою) }\end{array}$ & $\begin{array}{l}\text { Експресія: } \\
\uparrow \text { SNAIL } \\
\uparrow \text { ZEB2 }\end{array}$ & $\begin{array}{c}\text { Багато стромальних } \\
\text { клітин: фібробласти, } \\
\text { міофібробласти, гладкі } \\
\text { міоцити, В-лімфоцити } \\
\end{array}$ & $\begin{array}{l}\text { Е-кадгерин- } \\
\text { Віментин + }\end{array}$ & $\begin{array}{c}\text { 3В - 3,8 лет } \\
\text { Мішені терапії: } \\
\text { Імунні чекпоїнти }\end{array}$ \\
\hline $\begin{array}{c}\text { Базально/ } \\
\text { плоскоклітин- } \\
\text { ний }\end{array}$ & $\begin{array}{c}\text { Експресія: } \\
\uparrow \text { EGFR+ } \\
\uparrow \uparrow \uparrow \text { STAT3, } \\
\uparrow \uparrow \uparrow F O X M 1 \\
\downarrow \downarrow \text { PPARG, } \downarrow \downarrow \text { GATA3, } \\
\downarrow \downarrow \text { FOXA1- } \\
\text { Myтаціï: } \\
\text { TP53 }(61 \%) \\
\text { RB1 }(25 \%) \\
\end{array}$ & $\begin{array}{c}\text { Плоскоклітинне } \\
\text { диференціювання } \\
\text { Лімфоцитарна } \\
\text { інфільтрація: } \\
\text { CD8 + лімфоцити, NK } \\
\text { клітини }\end{array}$ & $\begin{array}{c}\text { Р-кадгерин+ } \\
\text { KRT5+ } \\
\text { KRT14+ } \\
\text { GATA3- } \\
\text { FOXA1- } \\
\text { E-кадгерин- } \\
\text { UPK1-3- } \\
\text { KRT20- }\end{array}$ & $\begin{array}{c}\text { Частіше у жінок } \\
\text { Стадія 3-4 } \\
\text { ЗВ - 1,2 рік } \\
\text { Мішені терапії: } \\
\text { Імунні чекпоїнти } \\
\text { Хіміотерапія }\end{array}$ \\
\hline $\begin{array}{l}\text { Нейроендо- } \\
\text { кринний }\end{array}$ & $\begin{array}{l}\text { Експресія: } \\
\uparrow \text { онкогени } \\
\text { Мутації: } \\
\text { TP53 (94\%) } \\
\text { RB1 }(39 \%)\end{array}$ & $\begin{array}{c}\text { Дрібноклітинні } \\
\text { карциноми з } \\
\text { нейроендокринним } \\
\text { диференціюванням }\end{array}$ & & $\begin{array}{c}\text { Найгірший прогноз } \\
\text { ЗВ - } 1 \text { рік } \\
\text { Імунотерапія? } \\
\text { Хіміотерапія? }\end{array}$ \\
\hline
\end{tabular}

Примітка: ЗВ - загальна виживаність. 


\section{Література/References}

1. Adam RM, DeGraff DJ. Molecular mechanisms of squamous differentiation in urothelial cell carcinoma: A paradigm for molecular subtyping of urothelial cell carcinoma of the bladder. Urol Oncol. 2015; 33 (10): 444-50. doi: 10.1016 / j.urolonc.2015.06.006.

2. Aine M, Eriksson P, Liedber F, Sjödahl G, Höglund M. Biological determinants of bladder cancer gene expression subtypes. Sci Rep. 2015; 5: 10957.doi: 10.1038 / srep10957.

3. Aine M, Eriksson P, Liedberg F, Höglund M, Sjödahl G. On Molecular Classification of Bladder Cancer: Out of One, Many. Eur. Urol. 2015; 68: 921-923.doi: 10.1016 / j.eururo.2015.07.021.

4. Bernardo C, Eriksson P, Marzouka N, Liedberg F, Sjödahl G, Höglund M. Molecular pathology of the luminal class of urothelial tumors J Pathol. 2019; 249 (3): 308-318. doi: 10.1002 / path.5318.

5. Biton A, Bernard-Pierrot I, Lou Y, Krucker C, Chapeaublanc E, Rubio-Pérez C. et al. Independent analysis uncovers the landscape of the bladder tumor transcriptome and reveals insights into luminal and basal subtypes. Cell Rep. 2014; 9 (4): 1235-1245. doi: 10.1016 / j.celrep.2014.10.035.

6. Chan KS, Espinosa I, Chao M, Wong D, Ailles L, Diehn M. et al. Identification, molecular characterization, clinical prognosis, and therapeutic targeting of human bladder tumor-initiating cells. Proc Natl Acad Sci USA 2009; 106 (33): 14016-14021. doi: 10.1073 / pnas.0906549106.

7. Choi W, Czerniak B, Ochoa A, Su X, Siefker-Radtke A, Dinney C, McConkey DJ. Intrinsic basal and luminal subtypes of muscle-invasive bladder cancer. Nat Rev Urol. 2014; 11 (7): 400-410. doi: 10.1038 / nrurol.2014.129.

8. Choi W, Porten S, Kim SS, Willis D, Plimack ER, Hoffman-Censits J. et al. Identification of Distinct Basal and Luminal Subtypes of Muscle-Invasive Bladder Cancer with Different Sensitivities to Frontline Chemotherapy. Cancer Cell. 2014; 25: 152-165. doi: 10.1016 / j.ccr.2014.01.009.

9. Damrauer JS, Hoadley KA, Chism DD, Fan C, Tiganelli CJ, Wobker SE. et al. Intrinsic subtypes of highgrade bladder cancer reflect the hallmarks of breast cancer biology. Proc Natl Acad Sci USA. 2014; 111: 3110-3115. doi: 10.1073 / pnas.1318376111.

10. Eriksson P, Aine M, Veerla V, Liedberg F, Sjödahl G, Höglund M. Molecular subtypes of urothelial carcinoma are defined by specific gene regulatory systems. BMC Medical Genomics 2015; 8: 25. doi: 10.1186 / s12920-015-0101-5.

11. Fishwick C, Higgins J, Percival-Alwyn L, Hustler A, Pearson J, Bastkowski S. et al. Heterarchy of transcription factors driving basal and luminal cell phenotypes in human urothelium. Cell Death Differ. 2017; 24: 809-818. doi: 10.1038 / cdd.2017.10.

12. Hedegaard J, Lamy $P$, Nordentoft I. Comprehensive transcriptional analysis of early-stage urothelial carcinoma. Cancer Cell. 2016; 30: 27-42. doi: 10.1016 / j.ccell.2016.05.004.

13. Ho PL, Kurtova A, Chan KS. Normal and neoplastic urothelial stem cells: Getting to the root of the problem. Nat Rev Urol. 2012; 9 (10): 583-594. doi: 10.1038 / nrurol.2012.142.

14. Hurst $C D$, Alder O, Platt FM. Genomic subtypes of non-invasive bladder cancer with distinct metabolic profile and female gender bias in KDM6A mutation frequency. Cancer Cell. 2017; 32: 701-15. doi: 10.1016 / j.ccell.2017.08.005.

15. Hurst CD, Platt FM, Taylor CF, Knowles MA. Novel tumor subgroups of urothelial carcinoma of the bladder defined by integrated genomic analysis. Clin Cancer Res. 2012; 18: 5865-5877. doi: 10.1158 / 10780432.CCR-12-1807.

16. Kamoun A, de Reyniès A, Allory Y, Sjödahl G, Robertson AG, Seiler R et al. A consensus molecular classification of muscle-invasive bladder cancer European urology. 2019; pii: S0302-2838 (19) 306955. doi: https://doi.org/10.1101/488460.

17. Knowles MA, Hurst CD. Molecular biology of bladder cancer: new insights into pathogenesis and clinical diversity. Nat Rev Cancer. 2015; 15: 25-41. doi: 10.1038 / nrc3817.

18. Lerner SP, McConkey DJ, Hoadley KA. et al. Bladder cancer molecular taxonomy: summary from a consensus meeting. Bladder Cancer. 2016; 2: 37-47. doi: 10.3233 / BLC-150037.

19. Lindgren D, Sjödahl G, Lauss M, Staaf J, Chebil G, Lövgren K. et al. Integrated genomic and gene expression profiling identifies two major genomic circuits in urothelial carcinoma. PLoS One. 2012; 7 (6): e38863. doi: 10.1371 / journal.pone.0038863.

20. McConkey DJ, Choi W, Dinney CP. New insights into subtypes of invasive bladder cancer: Considerations of the clinician. Eur Urol. 2014; 66 (4): 609-610. doi: 10.1016 / j.eururo.2014.05.006.

21. McConkey DJ, Choi W. Molecular Subtypes of Bladder Cancer. Curr Oncol Rep. 2018; 20 (10): 77. doi: 10.1007 / s11912-018-0727-5.

22. Mo Q, Nikolos F, Chen F, Tramel Z, Lee YC, Hayashi K. et al. Prognostic Power of a Tumor Differentiation Gene Signature for Bladder Urothelial Carcinomas. J. Natl. Cancer Inst. 2018; 110 (5): 448-459. doi: 10.1093 / jnci / djx243.

23. Robertson AG, Kim J, Al-Ahmadie H, Bellmunt J, Guo G. et al. Comprehensive Molecular Characterization 
of Muscle-Invasive Bladder Cancer. Cell. 2017; 171: 540-556.e25.doi: 10.1016 / j.cell.2018.07.036.

24. Satyal U, Sikder RK, McConkey D, Plimack ER, Abbosh PH. Clinical implications of molecular subtyping in bladder cancer Curr Opin Urol. 2019; 29 (4): 350-356. doi: 10.1097 / MOU.0000000000000641.

25. Sjödahl G, Eriksson P, Liedberg F, Höglund M. Molecular classification of urothelial carcinoma: global mRNA classification versus tumour-cell phenotype classification. J Pathol. 2017; 242 (1): 113-125. doi: 10.1002 / path.4886.doi: 10.1002 / path.4886.

26. Sjödahl G, Lauss M, Lovgren K, Chebil G, Gudjonsson S, Veerla S. et al. A molecular taxonomy for urothelial carcinoma. Clin Cancer Res. 2012; 18 (12): 3377-3386. doi: 10.1158 / 1078-0432.CCR-12-0077-T.

27. Sjödahl G, Lövgren K, Lauss M, Patschan O, Gudjonsson S, Chebil G. et al. Toward a molecular pathologic classification of urothelial carcinoma. Am J Pathol. 2013; 183 (3): 681-691. doi: 10.1016 / j.ajpath.2013.05.013.

28. Sjödahl G. Molecular Subtype Profiling of Urothelial Carcinoma Using a Subtype-Specific Immunohistochemistry Panel. Methods Mol Biol. 2018; 1655: 53-64. doi: 10.1007 / 978-1-4939-72340_5.doi: 10.1007 / 978-1-4939-7234-0_5.

29. Song D, Powles T, Shi L, Lirong Z, Ingersoll MA, Lu YL. Bladder cancer, a unique model to understand cancer immunity and develop immunotherapy approaches J Pathol. 2019; 249 (2): 151-165. doi: 10.1002 / path.5306.

30. Sulaieva ON, Stakhovskiy OE, Shapochka DO. Molecular pathology of urothelial carcinoma: prognostic and predictive biomarkers. Practical oncology. 2019; 2 (4): 29-40.

31. Tan TZ, Rouanne, M, Tan, KT, Huang, RY-J, And Thiery, J-P. Molecular Subtypes of Urothelial Bladder Cancer: Results from a Meta-cohort Analysis of 2411 Tumors. Eur. Urol. 2019; 75: 423-432. doi: 10.1016 / j.eururo.2018.08.027.

32. Thomsen MBH, Nordentoft I, Lamy P, Vang S, Reinert L, Mapendano CK. et al. Comprehensive multiregional analysis of molecular heterogeneity in bladder cancer. Sci. Rep. 2017; 7: 11702. doi: 10.1038 / s41598-017-11291-0.

33. Volkmer JP, Sahoo D, Chin RK, Ho PL, Tang C, Kurtova AV. et al. Three differentiation states risk-stratify bladder cancer into distinct subtypes. Proc Natl Acad Sci USA 2012; 109 (6): 2078-2083. doi: 10.1073 / pnas.1120605109.

34. Warrick JI, Sjödahl G, Kaag M, Raman JD, Merrill S, Shuman L et al. Intratumoral Heterogeneity of Bladder Cancer by Molecular Subtypes and Histologic Variants. Eur. Urol. 2019; 75 (1): 18-22. doi: 10.1016 / j.eururo.2018.09.003.doi: 10.1016 / j.eururo.2018.09.003.

35. Weinstein J, Akbani R, Broom B. et al. Comprehensive molecular characterization of urothelial bladder carcinoma. Nature 2014; 507: 315-322. doi: 10.1038 / nature12965.

36. Yoshihara K, Shahmoradgoli M, Martínez E, Vegesna R, Kim H, Torres-Garcia W. et al. Inferring tumour purity and stromal and immune cell admixture from expression data. Nat. Commun. $2013 ; 4: 2612$. doi: 10.1038 / ncomms3612. 